\title{
地域協働によるイノベーション人材教育 JSCOOP
}

JSCOOP : Education Program to Produce Innovative Personnel Cooperated with Local Industry

土 田 泰 子※ 1

Yasuko TSUCHIDA

井山 徹 郎※1

Tetsuro IYAMA
村上 祐 貴*1

Yuki MURAKAMI

床 井良 徳※1

Yoshinori TOKOI
外山茂浩 $1^{1}$

Shigehiro TOYAMA

赤 澤 真 一

Shin-ichi AKAZAWA

\section{池 田 富士雄 ${ }^{* 1}$ \\ Fujio IKEDA}

桐 生 拓*1
Taku KIRYU

\begin{abstract}
JSCOOP (Job Contents Search with Local Companies Based on Cooperative Education) is the practical subject in National Institute of Technology, Nagaoka College (NITN), which aims at producing innovative personnel who have abilities to find problems and solve them. 4th and 5th graders and advanced courses' students who participate in System Design Education Program in NITN attend this class and visit local companies to interview in order to get information about the target company and investigate current problems in each company. JSCOOP has 2 aspects; career education which enables students to understand the roles and importance of local industry, and practical education which provides students with opportunities to suggest their own ideas to solve practical problems. Cooperating with local companies, JSCOOP continues enhancing practical engineering education, raising innovative mind and bringing about new point of view and flexible collaboration through cross-field cooperation.

Keywords : Industry-Academia Collaboration, Regional Collaboration, Problem Based Learning, Problem Solving, Engineering Education

キーワード：産学連携, 地域貢献, 問題発見, 問題解決, 工学教育
\end{abstract}

\section{1.はじめに}

長岡工業高等専門学校 (以下, 長岡高専とする) では, 新たな発想・複眼的思考を涵養し，幅広い専門知識・技 術力を駆使して困難な課題を解決できる, 実践的で創造 的な技術者を養成することを目的とした学科・専攻科横 断型一貫教育プログラムを設けている。自らの専門分野 に関する確固たる知識・技術の上に，異分野の知識・技 術を修得し融合·昇華させるカリキュラムが, 学科 4 年, 5 年抢よび専攻科 1 年, 2 年のそれぞれ 2 年間に設定さ れている. 本取組は, 学科・専攻科の枠を超えた複数指 導体制, 教育内容によって時代の求める共通の課題に柔 軟に対応できる能力を養うことを目的として複数のプロ グラムを設定し，それぞれ本科のみで修了する「ベーシ ックコース」と本科・専攻科一貫の「エクスパートコー ス」から構成される。平成25年度に開設した「新エネル ギー創成教育プログラム」に加えて, 平成 26 年度「シス テムデザイン教育プログラム」を開設した。「システムデ ザイン教育プログラム」は，ヒトの安心につながるシス テムデザイン，モノの安全につながるシステムデザイン を具体的な研究課題として取り上げ, 複数の専門領域に 渡る諸問題のイノベーティブな解決策を導出可能な分野 横断的能力の素地を養うことを目的として設立された。

2017 年 3 月 10 日受付

※ 1 長岡工業高等専門学校
このシステムデザイン教育プログラムの中で, システム 思考・デザイン思考の実践として位置付けられ, 地域企 業との協働により実践されているのがJSCOOPである. 本論文では，システムデザイン教育プログラムの中で育 成する能力とカリキュラムについて述べ, 当該教育プロ グラムの中におけるJSCOOPの位置付けや教育内容につ いて言及した後, その教育的効果についての検証を行う.

\section{2. 学生が備えるべき能カとカリキュラム}

近年加速する少子高齢化による社会構造の変化が引き 起こす地方の人口減少や生産年齢人口の減少等の問題 は, 社会の個別分野に閉じた従来のアプローチでは対応 が難しく, 産官学の関係者が幅広く連携し, 科学技術イ ノベーションを起こす仕組みを構築することが期待され ている ${ }^{1)}$. 他方, 技術者が直面する環境問題やエネルギ 一問題などの課題は大規模・複雑化してきており, 解決 には人と人とのネットワーキングやチームで働く力の重 要性が強調されることが多い。 これを受け, 経済産業省 は2006年から「社会人基礎力」を提唱している.「社会 人基礎力」は前に踏み出す力, 考え抜く力, チームで働 く力の 3 つの能力から構成され, 職場や地域社会で多様 な人々と仕事をしていくために必要な産業人材の基礎的 な力とされている ${ }^{2)}$. 前に踏み出す力は, 主体性, 働き かけ力, 実行力の 3 つの要素から構成されており, 一歩 前に踏み出し, 失敗しても粘り強く取り組む力とされて 
表 1 学生が備えるべき能力とカリキュラムの対応

\begin{tabular}{|c|c|c|c|c|c|c|}
\hline \multirow{2}{*}{ 社会人基礎力 } & \multirow{2}{*}{\multicolumn{2}{|c|}{ モデルコアカリキュラム }} & \multicolumn{4}{|c|}{ 長岡高専システムデザイン教育プログラム科目 } \\
\hline & & & 本科 4 年 & 本科 5 年 & 専攻科 1 年 & 専攻科 2 年 \\
\hline 傾聴力 & \multirow{5}{*}{ 沉用的技能 } & コミュニケーションスキル & SLFD & BSPS & SSPS I & SSPS II \\
\hline 柔軟性 & & 合意形成 & SLFD & BSPS & EDE, SSPS I & SSPS II \\
\hline 発信力 & & 情報収集・活用・発信力 & & BSPS & SSPS I & SSPS II \\
\hline 課題発見力 & & 課題発見 & SLFD & BSPS & EDE, SSPS I & SSPS II \\
\hline 情況把握力 & & 論理的思考力 & SLFD & BSPS & DBTS, SSPS I & SSPS II \\
\hline 主体性 & \multirow{7}{*}{$\begin{array}{c}\text { 態度‧志向性 } \\
\text { (人間力) }\end{array}$} & 主体性 & & BSPS & SSPS I & SSPS II \\
\hline ストレスコントロール力 & & 自己管理力 & & BSPS & SSPS I & SSPS II \\
\hline 実行力 & & 責任感 & & BSPS & SSPS I & SSPS II \\
\hline 規律性 & & チームワークカ & SLFD & BSPS & EDE, SSPS I & SSPS II \\
\hline 働きかけ力 & & リーダーシップ & SLFD & BSPS & SSPS I & SSPS II \\
\hline - & & 倫理観 & SLFD & BSPS & SSPS I & DBTS, SSPS II \\
\hline 計画力 & & 未来志向性 & SLFD & BSPS & SSPS I & DBTS, SSPS II \\
\hline 創造力 & \multirow{2}{*}{$\begin{array}{l}\text { 総合的な学習経験 } \\
\text { と創造的思考力 }\end{array}$} & 創成能力 & SLFD & BSPS & EDE, SSPS I & SSPS II \\
\hline- & & エンジニアリングデザイン能力 & SLFD & BSPS & EDE, SSPS I & SSPS II \\
\hline
\end{tabular}

[表中の科目名略称について］※表中の太字はJSCOOP実施科目

SLFD : 自己啓発型課題学修, BSPS : プログラム研究基礎セミナー, EDE : エンジニアリングデザイン演習 (専攻科特別実験),

DBTS：ディベート技術学修, SSPS I ：プログラム研究特別セミナーI , SSPS II ：プログラム研究特別セミナーII

いる，考え抜く力は，課題発見力，計画力，創造力の 3 つの要素から構成されており, 疑問を持ち考え抜く力と されている，そして，チームで働く力は，発信力，傾聴 力，柔軟性，状況把握力，規律性，ストレスコントロー ル力の 6 つの要素から構成されており, 多様な人々と共 に，目標に向けて協力する力とされている．このように 社会人基礎力は 3 つの能力・12の能力要素から構成され るが，社会人として身に付けるべきこれらの能力の水準 は，企業と学生の間で大きな意識の差があるとされてい $ろ^{3)}$. 例えば, 粘り強さ, チームワーク力, 主体性, コ ミュニケーションといった能力は,「十分出来ている」と いう学生の認識に対し，「まだまだ足りない」というの が企業の認識である，その一方でビジネスマナー, 語学 力, 業界の専門知識, PCスキルといった能力は,「また まだ足りない」という学生の認識に対し，「できている. または,これからでよい」というのが企業の認識である. これらのことから, 粘り強さ, チームワーク力, 主体性, コミュニケーションといった能力を, 企業が求める水準 へと伸ばすという社会的ニーズがあると考えられる。

長岡高専を含む高等専門学校は, これまで数多くの実 践的技術者を輩出し, 我が国の経済成長を支えてきた。 しかし, 先述のような産業構造の変化, 科学技術の高度 化, 地域ニーズの変化等の社会状況の変化を受けて, 地 域及び世界のニーズを踏まえた新分野へ展開ができる技 術者の輩出とその教育体制の充実が求められている。専 門的かつ実践的な知識と世界水準の技術を有し, 自律的, 協働的，創造的な姿勢でグローバルな視野を持って社会 の諸問題に立ち向かう,科学的思考を身に付けた実践的・ 創造的技術者を養成するため，モデルコアカリキュラム （以下， MCC と称する）を導入し高等専門学校教育の質 保証を推進することなど，教育の質の向上及び改善のた めのシステムを構築することを目指している.この $\mathrm{MCC}$ では，高専教育のより一層の高度化を図るための各高専
独自の高度教育となる「モデル」として，技術者が備え るべき分野横断型能力を涵養するよう沉用的技能, 態度・ 志向性 (人間力), 総合的な学習経験と創造的思考力の 3つの要素を示している. 汎用的技能は, コミュニケー ション・スキル, 合意形成, 情報収集・活用・発信力, 課題発見, 論理的思考力から構成される. 態度・志向性 （人間性）は, 主体性, 自己管理能力, 責任感, チームワ ークカ, リーダーシップ, 倫理観（独創性の尊重, 公共 心), 未来志向性, キャリアデザインカから構成される. そして, 総合的な学習経験と創造的思考力は, 創成能力 とエンジニアリングデザイン能力から構成される。この ようにMCCの「モデル」では，3つの要素・14の能力 を技術者が備えるべきものとして挙げている.

そこで, 長岡高専システムデザイン・イノベーション センター (以下, 長岡高専SDICとする) では, MCCの 長岡高専独自の高度教育として, 社会の要請に応えるべ く人間力豊かなイノベーション人材の輩出を目的とした カリキュラム「システムデザイン教育プログラム」を設 計し, その運用を進めてきた. カリキュラムではイノべ ーションを生み出すための思考法としてシステム思考, デザイン思考を基本に捉え, 社会人基礎力として示され る12の能力要素とMCCの「モデル」で示される14の能 力を対応させながら, それらを涵養するように表 1 で示 す科目を配置した。

\section{JSCOOP}

JSCOOP (Job Contents Search with Local Companies Based on Cooperative Education）は, 地域産業界と連携 し, 課題抽出力, 課題解決力を備えたイノベーション人材 を育成することを目的とした実践的教育科目である。本 科目は本科 5 年「プログラム研究基礎セミナー」, 専攻科 2 年「プログラム研究特別セミナーI」及び専攻科 2 年 「プログラム研究特別セミナーIII」の中で実施している. 
JSCOOPの中で学生が取り組む事項は 2 つる。一つ 目は，県内の協力企業を対象として，歴史，保有技術な どを十分に把握した上で，当該企業に所属する専門技術 者に対して行う取材である。取材活動を通じて自らのキ ヤリアを継続的にデザインする能力を身に付ける. また, 取材で得た企業情報を基に，対象者によらず当該企業を 理解できる PR 記事を作成し，専門分野での情報収集や 情報発信能力を身に付ける。二つ目は, 取材活動を通じ て, 現在企業が抱えている問題の課題化と, その解決策 の提案である.

JSCOOPでは本科 5 年生, 専攻科 1,2 年生が立場を変 えながら，上記 2 つミッションに取組む。本科 5 年は 主に, 協力企業への取材活動全般を担当する. 専攻科 1 年生は, 本科 5 年の取材活動の指導を担うとともに, 企 業から抽出した問題を課題化し, その対策を考えるチー ムのコアとなる。専攻科 2 年生は, 本科 5 年生, 専攻科 1 年生の指導に加えて行動の評価を行う.

平成 28 年度は, エクスパートコース生である専攻科 1 年生 3 名が中心となって指導・評価を担当し, 教員も指 導・評価に加わり JSCOOPを実施した。 プログラム研究 基礎セミナーの受講人数は本科 5 年生 21 名であり, その 内訳は, 機械工学科 8 名, 電気電子システム工学科 4 名, 電子制御工学科 5 名, 物質工学科 2 名, 環境都市工学科 2 名であり, 本校のすべての学科から参加学生が出てい

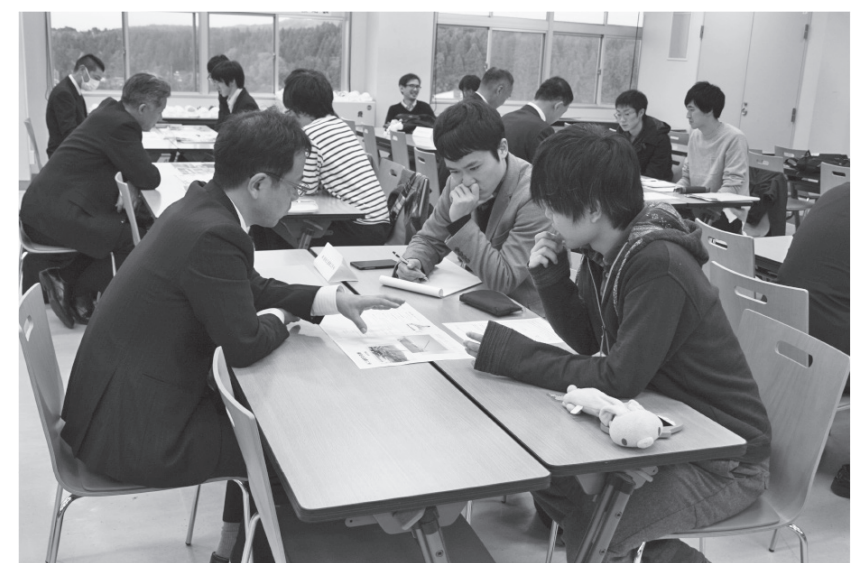

図 1 協力企業担当者との打ち合わせ

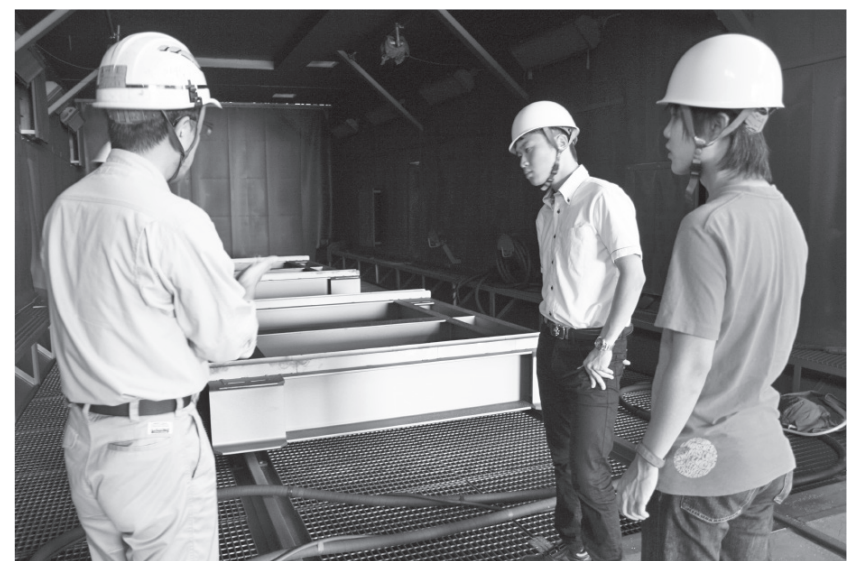

図 2 協力企業への取材
る状況である. 県内協力企業数は 15 社であり，すべて建 設関連業に携わる県内企業である.

取材を実施する前に企業担当者と取材方針およびPR 原稿のデザインを確認し, 取材当日までに合意形成を図 った（図 1 ). 夏季休業中の 1 日ないし 2 日間, 県内協力 企業に学生が数人のグループで訪問し, 取材活動を実施 するとともに, 実際の現場に出向いて, リアルタイムで 問題となっていることを抽出した.

企業側には, 出来るだけ学生の取材方針に即した取材 活動が展開できるように, 事前に社内調整を行って頂い た. 当日は, 学生の取材活動に即した取材活動が概ね実 行できた。また, 現状で企業が抱えている様々な問題を, 実際の現場を視察しながら説明を受けたため, 学生も問 題把握がスムーズにできたと思われる（図 2 ).

学生は, 取材を行うという立場からホスト側として能 動的に取り組む様子が見られた. また企業はクライアン 卜側として, 自社の問題解決と PRに繋がるよう積極的に 学生への教育に取り組む様子が見られた，本取組は，学 生がキャリアについて考える機会の一つであり, また学 科混成チームで取り組むため, 学生のファシリテーショ ンスキルを伸ばす絶好の場であると考えられる。学生が これまでに修得した知識・技術・技能を実践の場で活か す絶好の機会となっている.

各協力企業のPRパンフレットは, 学生が制作・編集し

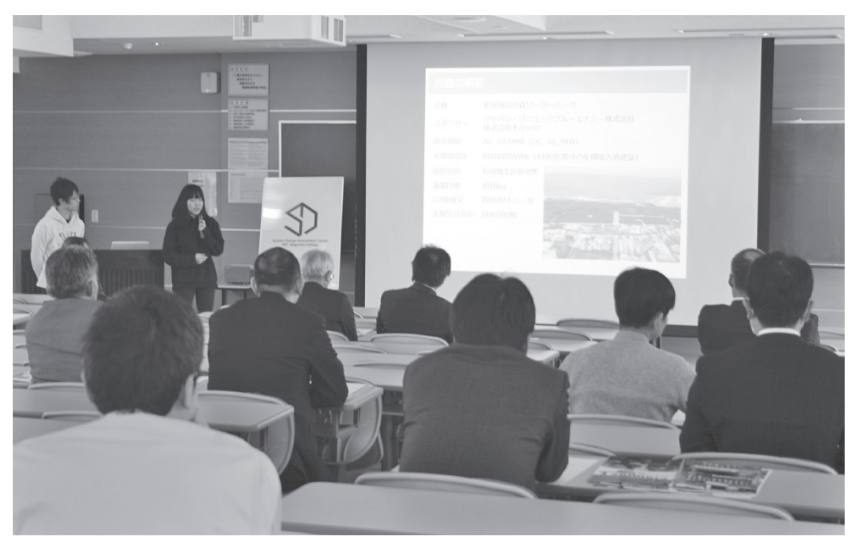

図 3 成果報告会 (学生による発表の様子)

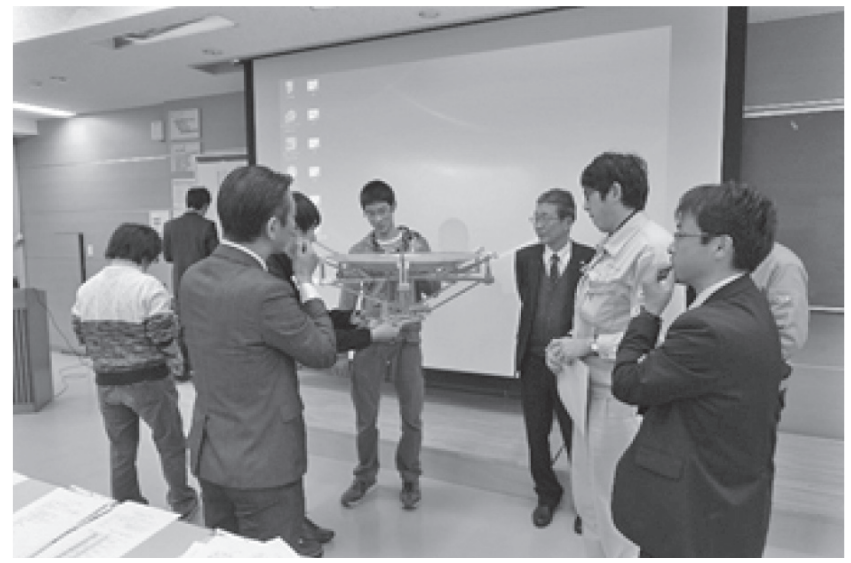

図 4 成果報告会（成果物の検討） 
た原稿を元に，業者による印刷を行っている，取材で得 た情報を学生が自由にレイアウトし，例年各チームの個 性が発揮されたものとなっている。このPR原稿は取材 を行った企業に報告として渡されるだけでなく，成果発 表会において他の参加学生や協力企業, さらに本取組に 関心を持つ地域企業にも共有され，また評価の対象とな る.

企業への取材を元に抽出した課題は，それぞれ学生に より統一の書式を用いて可視化された. 項目として問題, ジャンル, 場所・対象, 詳細, 制約条件, 現状の対応, 用語補足を設定し，図や写真等を用いて制作されている. コストや使用条件等の制約状況を意識して問題を課題化 しており，より現実的な活動実践となっている.

2 月に実施する成果報告会では, 学生が学科を交えた 2 ３名のチームにより, 得られた課題への解決策を提
案するプレゼンテーションを行っている（図 3 および図 4 ). 成果報告会には協力企業の担当者も参加して評価に 加わっている.

\section{4. 教育効果の検証}

JSCOOPの教育的効果を検証するため，学生および協 力企業に対してアンケート調查を実施した. 調査項目及 び集計結果を表 2 及び表 3 に示す．学生アンケートは回 収率 $79.1 \%$, 企業アンケートは回収率100\%である。回答 のうち「そう思う」及び「どちらかといえばそう思う」 を「YES」として、「そう思わない」及び「どちらかとい えばそう思わない」を「NO」として集計を行っている。

\section{1 学生アンケート集計結果}

学生アンケート集計結果（表 2 ）より, 学生は概ね本 取組に対して好意的にとらえていると言える. 項目 4〜

表 2 学生アンケート 調査項目と結果（回答数 19 , 回答率 $79.1 \%$ )

\begin{tabular}{|c|c|c|c|}
\hline & 項 & $\begin{array}{c}\text { YES } \\
(\%, \text { 回答数 })\end{array}$ & $\begin{array}{l}\mathrm{NO} \\
(\%, \text { 回答数 })\end{array}$ \\
\hline 1 & JSCOOPの活動に，積極的に取り組んだと思う & $100 \%(19)$ & $0 \%(0)$ \\
\hline 2 & JSCOOPでの取り組みのために必要な時間を, 十分に確保できたと思う & $52.6 \%(10)$ & $47.4 \%(9)$ \\
\hline 3 & JSCOOPの活動には，改善できる点があると思う & $94.7 \%(18)$ & $5.3 \%(1)$ \\
\hline 4 & JSCOOPの活動を通して，相手の意見を聴き，コミュニケーションをとる能力が向上したと思う & $100 \%(19)$ & $0 \%(0)$ \\
\hline 5 & JSCOOPの活動を通して，意見の違いや立場の違いを理解し，合意形成を行う能力が向上したと思う & $100 \%(19)$ & $0 \%(0)$ \\
\hline 6 & $\begin{array}{l}\text { JSCOOPの活動を通して, 自分の意見をわかりやすく伝える能力や，情報を集めたり発信した } \\
\text { りする能力が向上したと思う }\end{array}$ & $100 \%(19)$ & $0 \%(0)$ \\
\hline 7 & JSCOOPの活動を通して，現状を分析し，目的や課題を明らかにする能力が向上したと思う & $94.7 \%(18)$ & $5.3 \%(1)$ \\
\hline 8 & $\begin{array}{l}\text { JSCOOPの活動を通して, 自分と周囲の人々や物事との関係性を理解し, 客観的・論理的に認 } \\
\text { 識する能力が向上したと思う }\end{array}$ & $100 \%(19)$ & $0 \%(0)$ \\
\hline 9 & JSCOOPの活動を通して, 物事に進んで取り組む能力が向上したと思う & $78.9 \%(15)$ & $21.1 \%(4)$ \\
\hline 10 & JSCOOPの活動を通して，自己管理を意識して行動し，ストレスの発生源に対応する能力が向上したと思う & $52.6 \%(10)$ & $47.4 \%(9)$ \\
\hline 11 & JSCOOPの活動を通して，責任感の重要性を理解して目的を設定し，確実に実行する能力が向上したと思う & $94.7 \%(18)$ & $5.3 \%(1)$ \\
\hline 12 & $\begin{array}{l}\text { JSCOOPの活動を通して, 組織が効率的に機能するためのチームワークを理解し, 社会のルー } \\
\text { ルや人との約束を守る能力が向上した思う }\end{array}$ & $100 \%(19)$ & $0 \%(0)$ \\
\hline 13 & JSCOOPの活動を通して，リーダーの役割を理解し，他人に働きかけ巻き込む能力が向上したと思う & $84.2 \%(16)$ & $15.8 \%(3)$ \\
\hline 14 & して, 法令遵守の考えや工学技術者と & $84.2 \%(16)$ & $15.8 \%(3)$ \\
\hline 15 & $\begin{array}{l}\text { JSCOOPの活動を通して, 技術の発展と持続的社会のあり方に関連して課題の解決に向けたプ } \\
\text { ロセスを明らかにし準備する能力が向上したと思う }\end{array}$ & $84.2 \% \quad(16)$ & $15.8 \%(3)$ \\
\hline 16 & JSCOOPの活動を通して，現実を踏まえ，新しい価値を生み出す能力が向上したと思う & $84.2 \%(16)$ & $15.8 \%(3)$ \\
\hline 17 & $\begin{array}{l}\text { JSCOOPの活動を通して, 工学や他の分野の学習成果を集約し, 現実的な条件の範囲内で社会 } \\
\text { のニーズに合ったシステムや方法を開発する能力が向上したと思う }\end{array}$ & $89.5 \% \quad(17)$ & $10.5 \%(2)$ \\
\hline 18 & JSCOOPの活動を通して, 一歩前へ踏み出し, 失敗しても粘り強く取り組む力が向上したと思う & $78.9 \%(15)$ & $21.1 \%(4)$ \\
\hline 19 & JSCOOPの活動を通して，疑問を持ち，考え抜く力が向 & $89.5 \% \quad(17)$ & $10.5 \%(2)$ \\
\hline 20 & JSCOOPの活動を通して, 多様な人々とともに, 目標に向けて協力する力が向上したと思う & $100 \%(19)$ & $0 \% \quad(0)$ \\
\hline 21 & \multicolumn{3}{|c|}{ 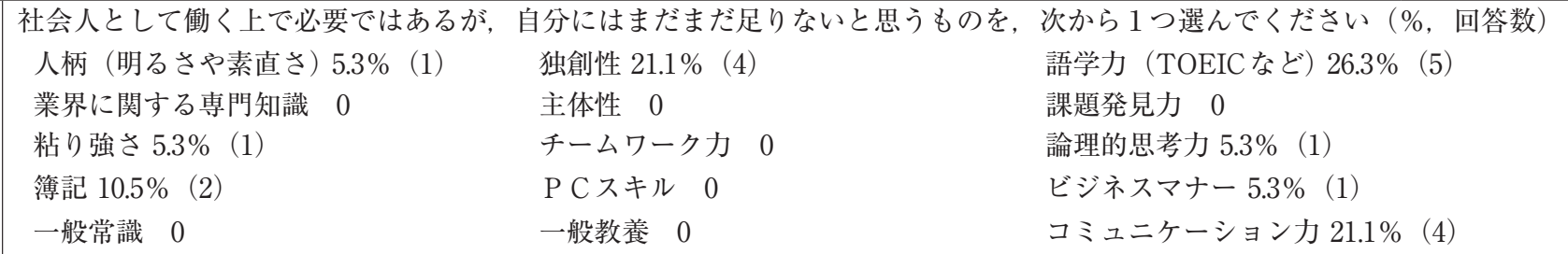 } \\
\hline 22 & JSCOOPの活動は，全体的に満足できるものだったと思う & $94.7 \%(18)$ & $5.3 \%(1)$ \\
\hline 23 & JSCOOPの活動を通して，地域企業への理解が深まったと思う & $94.7 \%(18)$ & $5.3 \%(1)$ \\
\hline 24 & JSCOOP の活動を通して，就職してみたい地域企業があった & $42.1 \%(8)$ & $57.9 \%(11)$ \\
\hline 25 & JSCOOPの活動全体を通して，専攻科生から適切な助言が得られたと思う & $84.2 \%(16)$ & $15.8 \%(3)$ \\
\hline 26 & 他の人にもシステムデザイン教育プログラムの受講を進めたいと思う & $73.7 \% \quad(14)$ & $26.3 \%(5)$ \\
\hline 27 & 今後もこのような教育活動を継続した方がよいと思う & $100 \%(19)$ & $0 \%(0)$ \\
\hline
\end{tabular}


表 3 企業アンケート 調査項目と結果（回答数 18 , 回答率100\%)

\begin{tabular}{|c|c|c|c|}
\hline & 調＼cjkstart查＼cjkstart項 & $\begin{array}{c}\text { YES } \\
\text { (回答数, \%) }\end{array}$ & $\begin{array}{c}\mathrm{NO} \\
\text { (回答数, \%) }\end{array}$ \\
\hline 1 & 取材および取材前後のやりとりについて，学生の応対は適切だった & $83.3 \%(15)$ & $16.7 \%(3)$ \\
\hline 2 & 学生の作成したPRパンフレットは, 満足できるものだった & $88.9 \%(16)$ & $11.1 \%(2)$ \\
\hline 3 & $\begin{array}{l}\text { JSCOOP参加学生の, 一歩前に踏み出し, 失敗しても粘り強く取り組む力は, 社会人として身 } \\
\text { に付けて欲しい能力水準に達していると思う }\end{array}$ & $72.2 \% \quad(13)$ & $27.8 \%(5)$ \\
\hline 4 & $\begin{array}{l}\text { JSCOOP参加学生の, 疑問を持ち, 考え抜く力は, 社会人として身に付けて欲しい能力水準に } \\
\text { 達していると思う }\end{array}$ & $77.8 \%(14)$ & $22.2 \%(4)$ \\
\hline 5 & $\begin{array}{l}\text { JSCOOP 参加学生の, 多様な人々とともに, 目標に向けて協力する力は, 社会人として身に付 } \\
\text { けて欲しい能力水準に達していると思う }\end{array}$ & $66.7 \%(12)$ & $33.3 \%(6)$ \\
\hline 6 & $\begin{array}{l}\text { JSCOOP 参加学生の, 自分の意見をわかりやすく伝える能力や, 相手の意見を聴き, コミュニケー } \\
\text { ションをとる能力は, 社会人として身に付けて欲しい能力水準に達していると思う }\end{array}$ & $66.7 \%(12)$ & $33.3 \%(6)$ \\
\hline 7 & JSCOOPの活動を通して, 高専生への理解が深まった & $94.4 \% \quad(17)$ & $5.6 \%(1)$ \\
\hline 8 & JSCOOPの活動を通して，採用してみたい学生があった & $88.9 \%(16)$ & $11.1 \%(2)$ \\
\hline 9 & JSCOOPの活動には，改善できる点があると思う & $83.3 \%(15)$ & $16.7 \%(3)$ \\
\hline 10 & JSCOOPの活動に, 今後も協力したいと思う & $94.4 \% \quad(17)$ & $5.6 \%(1)$ \\
\hline 11 & 他の企業にも JSCOOPへの参加を進めたいと思う & $94.4 \%(17)$ & $5.6 \%(1)$ \\
\hline 12 & 今後も学校でこのような活動を継続した方がよいと思う & $100 \%(18)$ & $0 \%(0)$ \\
\hline
\end{tabular}

21は本取組で育成することを目指す能力に関する項目で あり，項目 4〜15はMCCの「モデル」として示される 汎用的能力について, 項目 $16 \sim 21$ は社会人基礎力に関連 する能力についての設問である. 項目10の自己管理力に 関する設問では評価が分かれているが，他の項目は全般 的にYESの評価となっており，育成を目指した能力の伸 びを学生が感じていると言える結果となっている．項目 20は社会人基礎力に対する学生と企業の認識の違いに関 連して設定した質問であり，ここでは語学力やコミュニ ケーション力を挙げる学生が多かったが，企業が学生に 求めるコミュニケーション力を学生も必要と認識してい ることが明らかとなった，また，学生は独創性も重視し ており, 経済産業省が調査した学生群とは異なる認識を 本プログラム参加学生は示していると言える.

JSCOOPでは地産地消人材の輩出も狙いの一つとして おり, 協働により地域企業への理解を深め, 地元に就職 する学生を増やすことを本取組では目指している. 項目 23の回答から学生の理解がある程度深まっている様子が 伺えるが，一方で地域就職に関する質問である項目 24 へ の回答は分かれており，直接的な地域での人材確保には 結びつきにくい状況であると考えられる. しかし，数年 後あるいは十数年後のUターン就職先として, 可能性が あれば考えたいという学生の声もあった。

自由記述欄には，以下のような意見が寄せられた。

・話し合いの時間が少なく感じたので，もう少し授業 時間を多く取っても良いのではないか／・パンフレット 作成ではなく, 課題解決を主軸にしても良いと思う／。 授業は午後からの方が研究で忙しい時期にも集まりやす いと思う

自由記述でも述べられているように, 項目 2 の時間に関 する質問で回答が分かれており，多忙な高専生が本取組 への時間を確保するために, 何らかの工夫をする必要があ ったと推測される。 また，PRパンフレットの作成よりも， 課題解決に魅力を感じている学生の存在が示されている.

\section{2 企業アンケート集計結果}

企業アンケート集計結果（表 3 ）より，協力をいただ いた企業の担当者についても, 本取組に対して好意的に とらえられていると考えられる. 項目 $3 \sim 6$ は, 本取組 で育成することを目指している能力についての設問であ り，概ね育成できていると考えられる一方で，コミュニ ケーションカについては，まだ指導の余地があることが 示されていると言える.

自由記述欄には，以下のような意見が寄せられた。

・受入企業として当活動を受入れる体制が出来ていな い事を痛感した，今後, 学生の受入れ方を再考したい／ 課題解決について, 学科横断型で取組んでいるため, 一 つの学科では出てこない斬新な発想や奇抜なアイディア があり，それにより実用化の可能性も高くなると思う。 非常に良い取組みだと思う。また，学生も違う学科の人 と接することで, コミュニケーション能力が成長するの ではないかと思う／ここれまで，学内の様々な発表を聞 かせて頂き, 学生さん達の論文・パワーポイントのスラ イド作成能力はとても鍛えられているものと感じた．他 方, メールの文章能力には少し違和感を持っている. 昨 今, 社会でもメールは必須ツールとなっているが, 優れ た成果であっても, 客先との良好な関係構築が出来なけ れば良い評価は得らないことから，メールの文章もとて も大切と考えている/・社会に出てもっとも必要な能力 は課題解決能力なので, ぜひこのプロジェクトは継続し 発展させてほしい/JJSCOOPで社会とはどういうもの なのかを少し学んで貫えればと思う。一般学生にも広め ることで他の高専生との差別化ができると思う／・゙゙ー 夕などをうまくまとめることよりも, 結果を恐れずより クリエーティブな提案を考え出してもらいたい／・課題 解決への取り組みは，多様なアイデイアを抽出する目的 で少なくとも 3 人の班編成, あるいは取り組みの着手段 階（課題化の段階など）は複数の班が合同で行うなど, 試行してみてはどうだろうか 
企業側の学生の受け入れ体制については，学校側から の概要説明が十分でなかったとも考えられ, 今後の改善 項目の一つとして挙げられる. また, メールでの文章作 成についても, 学生への事前指導が必要であることが明 らかとなっており, 次年度以降の課題である。課題解決 の取組については, 課題への理解が重要なことから現在 は取材を行った学生のみが解決案を提示しているが，今 後は人数を増やしてアイディアを出し合い, その中から 最終案を選択する過程も組み入れていくことを検討した い.

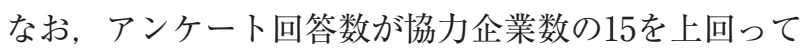
いることについては, 複数の担当者が対応した企業につ いて，それぞれの担当者が回答を行ったことによるもの である。

\section{5. 今後に向けて}

このようにJSCOOPは, 県内協力企業と密接な連携を 図りながら, 地域産業界が担う役割や意義を理解させる キャリア教育の側面を有するとともに, 問題の核心を的 確に捉え, 現場の状況に即した対策を提案できる力を涵 養する実践的教育科目となっている．本年度訪問企業数 10 社に対し抽出した課題数は 12 件であり, これを契機に 4 件の共同研究を得た。本取組の教育活動から共同研究 が生まれ, 研究の中で得たアイデイアや手法が教育に還 元されることで, 教育と研究とが密接に連携していると 言える。 また，JSCOOPで得られた課題は，現実の，い わば「生きている」課題であり,この課題を用いた課題 解決型授業を, キャリア教育として平成28年度より低学
年で導入している.これにより, 学生が教員を研究者と して捉え, 問題を研究課題として捉える視点を涵養する ことを目指している。このようにJSCOOPは地域企業か ら得る現実の課題をもとに, 学科や学年を越えた柔軟な 議論と発想を行うことを通して, 新たな解決策や新たな 連携がもたらされる可能性を秘めている.

JSCOOPを基盤とし，県内協力企業を他分野にも拡張 しながら, 今後も地域産業界との連携による実践的教育 を加速させる予定である.

\section{参 考 文 献}

1) 文部科学省: 平成28年版科学技術白書, 2016

2 ）経済産業省: 社会人基礎力, Webページ, www.meti. go.jp/policy/kisoryoku/, 参照日：2017-2-28

3 ）経済産業省 : 社会で活躍するために必要と考える能 力要素, 大学生の「社会人観」の把握と「社会人基礎 力」の認知度向上実証に関する調查, pp.7-9, 2010

\section{著者紹介}

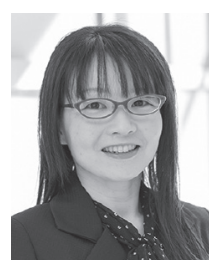

$\begin{array}{ll}\text { 土田 泰子 } \\ \text { 現 職 長岡工業高等専門学校一般教育科 } \\ \\ \text { 准教授 } \\ \text { 学 位 } & \text { 博士 (学術) } \\ \text { 所属学会 ヒューマンインタフェース学会, 日本デザイン } \\ \\ \text { 学会 } \\ \text { 連絡先 ytsuchida@nagaoka-ct.ac.jp }\end{array}$ 